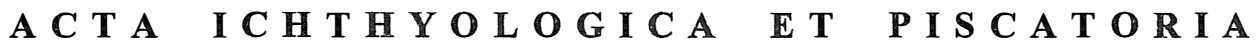 \\ Vol. XXVI, Fasc. 2 \\ Szczecin 1996
}

Bernard KŁYSZEJKO

Fish physiology

\title{
IMPACT OF CHLORINE ON PERFORMANCE ABILITY OF CARP (CYPRINUS CARPIO L.)
}

\author{
WPEYW CHLORU NA AKTYWNY WYSILEK KARPIA \\ (CYPRINUS CARPIO L.)
}

\section{Department of Fish Physiology, Agricultural University of Szczecin, Poland}

The present studies tested the impact of the total residual chlorine in the doses of $0.1-0.5 \mathrm{mg} / \mathrm{dm}^{3}$ on carp with the application of the general physical effort method. The ergometric tests revealed the immediate reaction for chlorine in the water was the drop in the performance ability of fish. In the concentrations of $0.3,0.4,0.5 \mathrm{mg} / \mathrm{dm}^{3}$ the value of work diminished down to: $70.0,45.0$, and $26.6 \%$ respectively of the norm established for the fish tested in the chlorine-free water.

\section{INTRODUCTION}

Chlorine in its active form does not occur in natural waters and its compounds (mostly hypochlorites) are introduced to water as disinfectants. As the outcome of the chlorinating process a number of different bindings of different stages of stability is being formed ( $\mathrm{HClO}$, $\mathrm{Cl}$, chloramines), as well as the molecular $\mathrm{Cl}$. All the above-mentioned forms are called "total residual chlorine"-TRC (Hemanowicz 1976).

Tap water destined for drinking and for the household use, in the result of chlorinating should contain, according to the standard, from 0.2 to $0.5 \mathrm{mg} / \mathrm{dm}^{3}$ of TRC (Anonymous 1990).

Usage of tap water containing chlorine in the fisheries practice may pose a threat to the fishes. It has been revealed that the concentrations of total chlorine as low as $0.003-0.05 \mathrm{mg} / \mathrm{dm}^{3}$ caused avoidance and escape responses in salmonid fishes fry, while warm-water species exhibited slightly lower sensibility (Cherry et al. 1977, 1982). Exposure of carp to $0.15-0.20 \mathrm{mg} \mathrm{Cl} / \mathrm{dm}^{3}$ within 12-16 hours leads to $25 \%$ mortalities (Lukjanienko 1974).

Strong oxidative properties of the chlorine bindings in the water cause, among others: the destruction of gill epithelium, leading to hypoxia (Bass 1977), osmoregulation distur- 
bance (Cohen 1977; Heath 1990), pathologic erythrocyte changes, and hemolytic anemia (Buckley 1976; Ferguson 1992).

The present work was intended to examine the impact of total residual chlorine on the functional reaction of the carp (the active physical effort capability) using the effort test, that has been proven suitable for evaluating the impact of toxic compounds on fishes (Kłyszejko 1992).

The analyzed impact considered the concentrations of TRC of $0.1-0.5 \mathrm{mg} / \mathrm{dm}^{3}$ occurring in the chlorinated tap water.

Active physical effort of the cultured fishes takes place particularly during transportation (compensation movements aimed at retaining balance). The intention of the presently conducted experiments was to simulate the conditions when the fish are placed in an aerated tank, immediately after it was filled with chlorinated tap water.

\section{MATERIAL AND METHODS}

The studies were conducted in Fall, on 83 individuals of carp weighting 375-420 g taken from the "Dolna Odra" fish farm.

The experiment was performed in $250-\mathrm{dm}^{3}$ aquaria at the water temperature of $14 \pm 2^{\circ} \mathrm{C}$ and $\mathrm{pH}$ 7.2-7.6.

The desired concentration of chlorine was achieved through single application of natrium hypochloride dose on the beginning of each experiment.

The concentration of TRC (free + bonded) was measured spectrophotometrically, using methyl orange and natrium bromide (Hermanowicz 1976).

The effort test was performed using the method of imposing on fish a load of general physical effort (Węgrzynowicz and Kłyszejko 1972a). The method involves attaching to the base of the dorsal fin of a fish-a float of predetermined displacement force. The float disturbs the hydrostatic balance and forces the fish to active work, proportional to the displacement force and the time of swimming.

The experiments were preceded by the empirical calculation of the load magnitude norm for the tested objects. It equaled the maximum displacement force of the float, the fish would be able to overcome, without signs of fatigue, throughout about 2 hours (Węgrzynowicz and Kłyszejko 1972b). Determined value of the displacement force of the float (kG), expressed as \% of the fish body mass $(\mathrm{kg})$ - so called load coefficient $(R)$ has been assumed as a standard of the work load, equal for both the control and the experimental fish.

Each fish in the experiments was employed for single trial only. To estimate the active effort in work units $(\mathrm{J})$, the angle was measured between the longitudinal axis of the fish and the surface of the water, as well as the speed and time of the active swimming under the 
load. All these allowed to calculate the distance covered by a fish from its placement in the experimental aquarium and the seizure of locomotion movements.

The number of fish used in the control and in the experimental groups for each studied TRC concentration was 15 or 16 individuals.

Statistical variability with the confidence level $Q=0.95$ was calculated using t-Student test.

\section{RESULTS}

The work load norm for the studied material was empirically determined on 16 randomly selected fish. It was revealed that in the chlorine-free water at the temperature of $14^{\circ} \mathrm{C}$ the fish swam for 2 hours without signs of fatigue-when the displacement force of the float did not exceed $4.9 \%$ of the body mass. Balancing this load the fish moved at the average speed of $0.125 \mathrm{~m} / \mathrm{s}$ at the oblique position against the water surface at the angle of $38-41^{\circ}$. Determined herewith value $(R=4.9 \%)$ has been assumed as the load norm in the test experiment.

Table 1

The effectof total residual chlorine (TRC) on active swimming time and performance ability of carp

\begin{tabular}{|c|c|c|c|}
\hline $\begin{array}{c}\text { Total } \\
\text { residual } \\
\text { chlorine } \\
\left(\mathrm{mg} / \mathrm{dm}^{3}\right)\end{array}$ & $\begin{array}{c}\text { Number } \\
\text { of fish }\end{array}$ & $\begin{array}{c}\text { Swirnming } \\
\text { time } \\
\text { (min) }^{1}\end{array}$ & $\begin{array}{c}\text { Work performed } \\
\text { (J/kg of body } \\
\text { weight })^{1}\end{array}$ \\
\hline 0,0 & 15 & $122 \pm 14,7$ & $504.3 \pm 18.61$ \\
0,1 & 15 & $115 \pm 12,8$ & $483.2 \pm 14.43^{*}$ \\
0,2 & 15 & $110 \pm 13,2$ & $462.2 \pm 14.95^{*}$ \\
0,3 & 16 & $84 \pm 14,9$ & $353.0 \pm 15.62$ \\
0,4 & 15 & $54 \pm 12,3$ & $226.9 \pm 15.11$ \\
0,5 & 15 & $32 \pm 11,4$ & $134.5 \pm 12.40$ \\
\hline
\end{tabular}

${ }^{1}$ Arithmetic means \pm standard deviation.

* Statistic insignificance (in comparison to control group).

Performance ability of the carp was tested at the following TRC concentrations in the water: $0.1,0.2,0.3$, 0.4 , and $0.5 \mathrm{mg} / \mathrm{dm}^{3}$. The results presented in Tab. 1 showed, that in the chlorine-free water (control group) the fish under load swam, without signs of fatigue for about 2 hours, performing at that time work of $504.3 \mathrm{~J} / \mathrm{kg}$ of their body mass. The presence of the concentrations of 0.1 and $0.2 \mathrm{mg} \mathrm{Cl} / \mathrm{dm}^{3}$ in the water initiated the tendency towards diminishing the performance ability (changes statistically insignificant). Under the higher concentrations of the chlorine $\left(0.3-0.5 \mathrm{mg} / \mathrm{dm}^{3}\right)$ the test showed statistically significant drop in the work value. Assuming the work values of the control group as $100 \%$ (Fig. 1), it is evident that the chlorine concentration of $0.4 \mathrm{mg} / \mathrm{dm}^{3}$ lowered the performance ability more than a half (down to $45 \%$ ), while the concentration of $0.5 \mathrm{mg} / \mathrm{dm}^{3}$ - down to $26.6 \%$.

The monitoring of the behavioral signs has revealed that immediately after placing the fish in the experimental aquarium, signs of anxiety occurred, as well as attempts of detaching from the float, and acceleration of the respiratory movements. After few minutes, both 


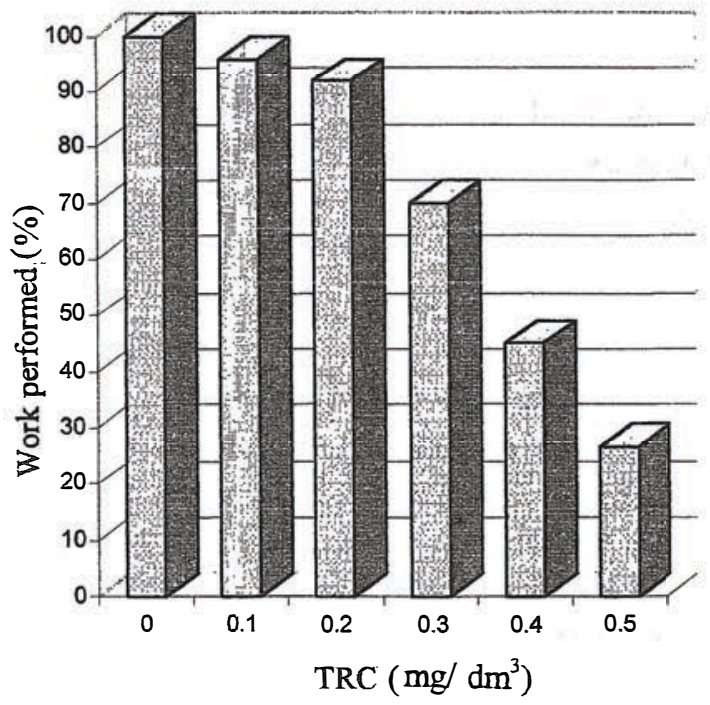

Fig. 1. The effect of total residual chlorine (TRC) on performence ability of carp controlled fish and those exposed to the concentrations of the chlorine of $0.1-0.2 \mathrm{mg} / \mathrm{dm}^{3}$ adapted themselves to the conditions of experiment.

Fish exposed to the impact of the concentrations of $0.3-0.5$ $\mathrm{mg} \mathrm{Cl} / \mathrm{dm}^{3}$ exhibited prolonged excitement period, periodical irregularity of the respiration movement and intensified mucus secretion. After the completion of the test and transferring the fish to fresh, uncontaminated water, these symptoms ceased to occur and no mortalities were recorded within 48 hours after the experiment.

\section{DISCUSSION}

Commonly used in fish toxicology the survival test $\mathrm{LC}_{50}$ or $\mathrm{LD}_{50}$ has limited suitability for the analysis of the impact of sublethal concentrations, because behavioral symptoms of fishes are similar or sometimes even identical for different toxicants. The methods allowing to asses the state of physical form of fishes based on swimming strength, fatigue time, critical speed of fishes, performance index etc. (Davis et al. 1963; Kutty 1968; Kutty and Saunders 1973; Waiwood and Beamish 1978) need sophisticated tunnels and rotation systems.

The test used in the present work is simple technically and allows to express energetic output of fish as work units. On top of that, the forced active physical effort accelerates the course of physiological processes and enables identification of the effects of the stimuli in shorter time or under lower concentration of a factor.

The results of the test have shown that the total residual chlorine within the range of concentrations allowed for the tap water, and under the exposure time of 2 hourssubstantially lowers performance abilities of the carp. It is likely that such depression, as an immediate reaction - is linked mainly to the aggressive action of chlorine on respiratory epithelium of the gills and as a consequence-limited gas exchange, as confirmed for the other fish species by the other authors (Bass et al. 1977; Cohen 1977; Ferguson 1992; Zeitoun et al. 1977). 
The acquired results have shown that in the initial concentrations of $0.1-0.2$ $\mathrm{mg} \mathrm{Cl} / \mathrm{dm}^{3}$ the lowering of the performance ability of fish were statistically insignificant, It would indicate that under short exposure time with TRC concentration not exceeding $0.2 \mathrm{mg} / \mathrm{dm}^{3}$ intensive aeration of water, and associated accelerated diffusion of chlorine to the atmosphere-is able to limit its toxic effect.

\section{CONCLUSION}

Concentrations of the total residual chlorine within the range occurring in the tap water $\left(0.3-0.5 \mathrm{mg} / \mathrm{dm}^{3}\right)$ respectively reduces performance ability of the carp down to $70-26.6 \%$ of the norm established in chlorine-free water,

\section{REFERENCES}

Anonymous, 1990: Rozporządzenie Ministra Zdrowia i Opieki Społecznej z dnia 4 maja 1990 r. [Disposition of the Minister of Health and Welfare dated 4 May 1990]. Dziennik Ustaw Nr 36, poz. 205, p. 479. (In Polish).

Bass M.L., C.R. Berry Jr., A.G. Heath, 1977: Histopathological effects of intermittent chlorine exposure on bluegill (Lepomis macrochirus) and rainbow trout (Salmo gairdneri). Water Res., 11: 731-735.

Buckley J.A., 1976: Heinz body hemolytic anemia in coho salmon (Oncorhynchus kisutch) exposed to chlorinated wastewater. J. Fish. Res. Bd Can., 34: 215-224.

Cherry D.S., S.R. Larrick, K.L. Dickson, R.C. Hoehn, J. Cairns jr., 1977: Significance of hypochlorous acid in free residual chlorine to the avoidance response of spotted bass (Micropterus punctatus) and rosyface shiner (Notropis rubellus). J. Fish. Res. Bd Can., 34: 1365-1372.

Cherry D.S., S.R. Larrick, J.D. Giattina, J. Cairns Jr., J. Van Hassel, 1982: Influence of temperature selection upon the chlorine avoidance of cold-water and warmwater fishes. Can. J. Fish. Aquat. Sci., 39: 162-173.

Cohen G.M., 1977: Influence of cations on chlorine toxicity. Bull. Env. Contam. Toxicol., 18 :131137.

Davis G.E., J. Foster, C.E. Warren, P. Durdoroff, 1963: The influence of oxygen concentration on the swimming performance of juvenile Pacific salmon at various temperatures. Trans. Amer. Fish. Soc., 92: 111-124.

Ferguson H.W., 1992 : Systemic Pathology of Fish. Iowa State University Press/Ames, 5: 90-103.

Heath A.G., 1990: Water Poliution and Fish Physiology, CRC Press, 3: 31-49.

Hermanowicz W., 1976: Fizykochemiczne badanie wody i ścieków [Physical and chemical testing of water and sewage]. Arkady, Warszawa: 159-180. (In Polish).

Kłyszejko B., 1992: Ocena wpływu Chlorfenwinfosu na aktywny wysiłek karpia (Cyprinus carpio L.) metoda testu wysiłkowego [The effect of Chlorphenvinphos on performance ability of carp (Cyprinus carpio L.) by the method of application of physical effort to the fish]. Zesz. Nauk. AR Szczecin, 150: 3-10. (In Polish).

Kutty M.N., 1968: Influence of ambient oxygen on the swimming performance of goldfish and rainbow trout. Can. J. Zool., 46: 647-653. 
Kutty M.N., R.L. Saunders, 1973: Swimming performance of young Atlantic salmon (Salmo salar) as affected by reduced ambient oxygen concentration. J. Fish. Res. Bd Can., 30: 223227.

Lukjanienko W.J., 1974: Toksykologia ryb [Toxicology of fishes]. PWRiL, Warszawa: 21-120. (In Polish).

Waiwood K.G., F.W.H. Beamish, 1978: Effects of copper, pH and hardness on the critical swimming performance of rainbow trout (Salmo gairdneri Richardson). Water Res., 12: 611-619.

Weggrzynowicz R., B. Klyszejko, 1972a: Method for application of physical effort to fish. Acta Ichth. Piscat., 2, 1: 91-94.

Węgrzynowicz R., B. Kłyszejko, 1972b: Specific adaptability to dynamic effort of fishes Abramis brama (L.), Rutilus rutilus (L.), Perca fluviatilis L., Anguilla anguilla (L.). $\quad$ Acta Ichth. Piscat., 2, 2: 21-24.

Zeitoun I.H., L.D. Huges, D.E. Ullery, 1977: Effect of shock exposures of chlorine on the plasma electrolyte concentrations of adult rainbow trout (Salmo gairdneri). J. Fish. Res. Bd Can., 34: 1034-1039.

Bernard KLYSZEJKO

\section{WPŁYW CHLORU NA AKTYWNY WYSIŁEK KARPIA (CYPRINUS CARPIO L.)}

\section{STRESZCZENIE}

Karpie o masie $375-420$ g poddano testowi wysiłkowemu $\mathrm{w}$ wodzie zawierającej $0,1-0,5$ $\mathrm{mg} / \mathrm{dm}^{3}$ chloru ogólnego pozostałego. Zastosowano metodę własną obciążania ryb ogólnym wysiłkiem fizycznym. Stwierdzono, że natychmiastową reakcją ryb był spadek możliwości wysiłkowych proporcjonalny do wzrostu stężenia chloru $\mathrm{w}$ wodzie. W porównaniu $\mathrm{z}$ normą pracy ustaloną $\mathrm{w}$ wodzie wolnej od chloru $(504 \mathrm{~J} / \mathrm{kg}$ masy ciała $=100 \%)$, wartość pracy w koncentracjach 0,$3 ; 0,4 ; \mathrm{i} 0,5$ $\mathrm{mg} \mathrm{Cl} / \mathrm{dm}^{3}$ obniżyła się statystycznie istotnie do odpowiednio: 70,0; 45,0 i $26,6 \%$ normy.

Received: 3 June 1996

Authors' address;

Bernard Kłyszejko PhD DSc Prof

Department of Fish Physiology

Agricultural University of Szczecin

Kazimierza Królewicza 4, 71-550 Szczecin, Poland 